\title{
Paremias in the Plays of Juan Pérez de Montalbán
}

\section{Las paremias en la obra dramática de Juan Pérez de Montalbán}

JOHN T. CULL

Departamento de Español

College of the Holy Cross

P. 0. 113A, One College Street. MA 01610. EE.UU.

jcull@holycross.edu

Orcid ID: 0000-0002-9017-9619

Resumen: Este estudio propone catalogar por orden alfabético las paremias que se incluyen en las obras dramáticas del malogrado poeta madrileño y amigo y discípulo de Lope de Vega, Juan Pérez de Montalbán, como manifestación de una convención muy popular en las comedias del Siglo de Oro: la incorporación sistemática de proverbios, refranes y otros tipos de paremias en el texto dramático, generalmente en boca del gracioso. Dicho corpus se basa en un total de 46 dramas, que incluyen 25 comedias universalmente aceptadas como auténticas, 11 comedias de autoría probable y 10 comedias de atribución dudosa. Una vez determinado el corpus, se procede a un breve análisis de la función de las paremias en la comedia aurisecular en general, y en la obra dramática de Pérez de Montalbán en concreto.

Palabras clave: Juan Pérez de Montalbán. Proverbios. Refranes. Paremias. Convenciones.
RECIBIDO: 24 DE JUNIO DE 2016 ACEPTADO: 22 DE SEPTIEMBRE DE 2016

\begin{abstract}
This study seeks to catalogue in alphabetic order the paremias that are included in the dramatic works of the ill-fated Madrid poet and friend and disciple of Lope de Vega, Juan Pérez de Montalbán, as a manifestation of a very popular convention in Spanish Golden Age dramas: the systematic incorporation of proverbs, refrains and other paremias in the dramatic text, generally issuing from the mouth of the gracioso. This corpus is based on a total of 46 dramas, that include 25 plays universally accepted as authentic, 11 plays of probable authorship and 10 plays of dubious attribution. Once the corpus is established, the article proceeds to a brief analysis of the function of paremias en Golden Age comedy in general, and in the dramatic works of Pérez de Montalbán in particular.
\end{abstract}

Keywords: Juan Pérez de Montalbán. Proverbs. Refrains. Paremias. Conventions. 
$\mathrm{P}$ aremias are a very common feature in Spanish Golden Age drama, and yet, in the hundreds of articles included in the journal Paremia in its 24 issues published to date, only one deals specifically with refrains in the comedia (Oddo Bonnet). This is surprising given the indisputable importance of paremias in Golden Age theater. José de Jaime Gómez and José María de Jaime Lorén have documented 329 Spanish literary works from the 16th-18th centuries that feature paremias as their titles, and practically all of them are plays, representing 365 different authors. These critics highlight the "astucia de muchos autores para situar a la cabecera de sus obras refranes y dichos sentenciosos que sirvieran de reclamo, de gancho para atraer a sus representaciones la mayor cantidad posible de público" (302). But paremias were not only exploited for the titles of Golden Age plays. Although they were incorporated systematically into the dramatic text by most major playwrights, their presence and function remain largely undocumented. In this study I seek to establish the significant corpus of paremias in the dramatic works of Juan Pérez de Montalbán and comment briefly on their function and significance.

What exactly constitutes a paremia? The Oxford English Dictionary defines paremia as "A proverb or adage; an aphorism". Such a definition allows for the inclusion of set phrases and other colloquial locutions that some critics might not consider to be proverbial in the strictest sense of the term. Gonzalo Correas included in his compilation not only proverbs and refrains but also, as indicated in the book's title, "otras fórmulas comunes de la lengua castellana". Julia Sevilla Muñoz has observed that the distinctive traits of a paremia include: "Ser un enunciado breve, sentencioso, consabido, de forma fija y con características linguísticas propias" (15). Nevertheless, there is no single definition of the term $p a$ remia that is universally accepted. Even for something as apparently simple and straightforward as a proverb, Mieder laments: "Hasta podríamos llegar a afirmar que hay más intentos de definición del proverbio que proverbios en sî" (18).

Paremiologists nonetheless distinguish a number of clearly demarcated categories of paremias, whether from a linguistic perspective (Navarro Domínguez; Anscombre), or from a terminological and conceptual point of view. Such is the case in the very pragmatic and useful study by Sevilla Muñoz and Crida Álvarez. In their taxonymy of paremias, these critics establish two main divisions: paremias de origen conocido y uso preferentemente culto (subdivided into the categories of proverbios and aforismos) and paremias de origen anónimo y uso preferentemente popular (subdivided into the categories of refranes, frases proverbiales, locuciones proverbiales and dialogismos) (113). It is perhaps the refrán that 
is encountered most frequently in Golden Age texts. It is a type of paremia that rests on the border between the learned and popular tradition, for although it is popular and anonymous in origin, it normally conveys a moralizing and didactic message, as we see in the definition of refrán provided in the 1737 Diccionario de Autoridades: "El dicho agudo y sentencioso, que viene de unos en otros, y sirve para moralizar lo que se dice o escribe".

Alberto Zuluaga has also contributed some helpful observations on the function of paremias in literary texts. His term for paremias in the broadest sense is unidades fraseologicas or fraseologismos, which he then divides into two sub-categories: enunciados fraseológicos (refrains, proverbs, adages, sentences, maxims, wellerisms, dialogisms) and locuciones proverbiales, which consist of a predicate, but which lack a subject in order to form a complete sentence. As an example of the latter, he cites: "ir por lana y volver trasquilado" (631). One function that both types share in common is "facilitar y simplificar al máximo tanto la formulación del mensaje por parte del autor como la recepción por parte del lector u oyente, diciendo algo mediante una construcción lingüística ya hecha y conocida en la comunidad respectiva" (631).

Among the other functions for paremias established by Zuluaga, two of special interest are the función icónica (634) and the función lúdico-poética (635). In the first instance, the paremia evokes a concrete visual image, something that a spectator can visualize in the mind's eye, a form of verbal decoration in a playing space largely devoid of adornment. An example from a play by Pérez de Montalbán is found in Segvnda parte del Séneca de España, Don Felipe Segvndo, when the King refuses to name Don Francisco Monsalve Portocarrero as Corregidor de Málaga due to his short stature: "da risa en lugar de miedo, / y trae la soga arrastrando / para qualquiera desprecio" (f. 32v). This vivid visual image reinforces the monarch's notion that his lack of height will cause those he governs to disrespect him and even put him in grave danger. In the second instance, $\mathrm{Zu}$ luaga cites as his example of a ludic-poetic function the final refrain in the Quijote: "En los nidos de antaño no hay pájaros hogaño" (635), which produces an impact on the receptor by means of its "musicalidad y la rima, una nota de gracia a esa resignada despedida que ha encontrado en él expresión adecuada" (636). A good example of a paremia with this type of function in Pérez de Montalbán can be found in truncated form in Complir con sv obligación when Mendoça chides the false bravado of Don Juan, who threatens to kill the Marqués, with: "Esso es hablar de la mar" (f. 63v). The full version of the paremia is Hablar de la mar, y en ella no entrar, thus Mendoça indirectly and playfully accuses his mas- 
ter of uttering an empy boast. Without doubt, a great number of the paremias in Spanish Golden Age theater in general, and in Juan Pérez de Montalbán in particular, are intended to be playful and provoke laughter in the audience.

The Portuguese dramatist Gil Vicente was instrumental in introducing proverbs and refrains into the repertory of conventions routinely exploited by Spanish Golden Age dramatists, as López Castro and Postigo Aldeamil have demonstrated in their respective studies. The ill-fated dramatist Juan Pérez de Montalbán ${ }^{1}$ incorporated proverbs, refrains and other types of paremias systematically into his plays. Like so many other writers of the period, he not only exploited paremiology, that is to say, "the study of proverbs and proverb lore" (OED), for the titles of some of his works (La ganancia por la mano, or his novella Al cabo de los años mil), but he also wove them deftly into his dramatic texts to such an extent that they become one of the defining traits of his style. In what follows, I will document the paremias that I have found in my reading of the dramatic corpus of Pérez de Montalbán and speculate briefly on their function and significance, inviting others to contribute more in-depth analyses in future studies. ${ }^{2}$

Establishing the corpus of paremias in the dramatic works of Juan Pérez de Montalbán is challenging due to the disputed authorship of a fair number of the plays as well as the difficulty in separating proverbs, aphorisms, refrains and maxims from other common locutions that could be considered paremias in the broadest acceptance of the term. In the table that follows, I include in an alphabetical listing only those proverbs and refrains that I have found in my reading of 46 plays authored by or attributed to Juan Pérez de Montalbán that most readers would not dispute. The first column cites the paremia in its standard form. The second column chronicles the version of it found in the text of the plays. The third column gives the form of the paremia as found in the compilation of Gonzalo Correas, or in just a few cases, in collections by other paremiologists of the period. Paremias from the dubious plays are indicated in the first column with an asterisk.

1. The playwright's descent into madness, possibly as a result of a brain tumor, is chronicled by Dixon 2013, 530-31.

2. To the extent possible, I cite from the plays published in the collaborative research project "Un autor madrileño recuperado: Juan Pérez de Montalbán”, directed by Claudia Dematté, who has assembled an impressive team of scholars to issue critical editions of the plays of Pérez de Montalbán, to publish studies on the author's work and to offer in digital format documents related to his biography, editions of the works, and information on Madrid of the period. To date, two volumes of the Obras de fuan Pérez de Montalbán have resulted from this collaboration of a total of ten planned by Edition Reichenberger. 


\section{Proverb or Refrain \\ * A buen entendedor, breve hablador / A buen entendedor, pocas palabras; o poca parola \\ * A cada puerco le viene su San Martín}

A cureña rasa, tirar sin mira

* A esotra puerta, que ésta no se abre

A hambre no bay mal pan

Al mozo vergonzoso, el diablo lo llevó a Palacio

* Al villano, danle el pie y toma la mano

Allá van leyes: do quieren Reyes

Andar, andar, que el rabo está por desollar
Pérez de Montalbán Play

ya sé lo que me dizes, / que al buen entendedor; / no quiero más dezirte. El diuino Portugués San Antonio de Pádua. (f. 157v)

esperando que algún día / como a los puercos de España, / me venga mi San Martín. Lucha de amor y amistad (Unpaginated: p. 29 of pdf)

y no como yo, que traigo / a cureña rasa el suelo.

La puerta Macarena, Primera parte (p. 4)

De qué estás tan pensatiuo, / a señor, a essotra puerta, / si acaso duermes despierta, / y responde si estás viuo. Amor, Lealtad, y Amistad (f. 178v)

A la hambre no hay pan malo. El bijo del Serafín, San Pedro de Alcántara (Obras 1.2, p. 65)

Aduierte, que al vergonçoso / el diablo lleua a Palacio. Un gusto trae mil disgustos (f. 8r)

Y merece que vn villano / le pague de esta manera, / pues dándole el pie, espera / a que se tome la mano. Amor, lealtad y amistad (f. 187v)

que en los Reyes van las leyes / donde ellos quieren que vayan. La puerta Macarena. Primera parte (p. 12)

Pues no tan locos, / que falta por desollar, / etcétera.

Teágenes, y Clariquea (f. 134r)

\section{Documentation Source}

Correas: A buen entendedor, breve hablador / A buen entendedor, pocas palabras; o poca parola

Correas: A cada puerco le viene su San Martín. (Castiga los que piensan que no les ha de venir su día, y llegar al pagadero. Por San Martín se matan los puercos, y de esto se toma la semejanza y con forma con el otro que dice: No hay plazo que no llegue)

Correas: A cureña rasa, tirar sin mira. (Metáfora de ballesta, que no ponen señal de puntería. Cureña es la tabla de la ballesta)

Correas: A esotra puerta, que ésta no se abre (Cuando no responde un sordo u otros)

Correas: A hambre no bay mal pan; A gran hambre no bay pan malo, ni duro, ni bazo; A gana de comer no bay mal pan, ni agua mala a gran sed

Correas: Al mozo vergonzoso, el diablo lo llevó a Palacio

Correas: Al villano, danle el pie y toma la mano

Vallés: Allá van leyes: do quieren Reyes

Correas: Andar, andar, que el rabo está por desollar 


\author{
A primera vayas, y treinta $y$ \\ nueve hagas \\ * Aun esto sería el diablo \\ * Aunque seas prudente viejo, \\ no desdeñes el consejo
}

Cada uno dice de la feria como le va en ella

Dádivas quebrantan peñas y bacen venir de las greñas

* De vna parte me cerca Duero, y de otra peña tajada, no sé dónde me vaja

Echarlo a doce, y nunca se venda

El amor lo vence todo

El conejo ido; y el consejo, venido

El dinero todo lo puede y vence

El lobo en la conseja
Esso es tener treinta y nueue / para loco. La toquera vizcayna (f. 143v)

Aun esto el diablo sería. El sufrimiento premiado (f. 264v)

Y más que prudentes son / los que mudan parecer. $L a$ mudanza en el amor (p. 175)

y de Príncipes prudentes / es saber mudar de intento.

El principe prodigioso y defensor de la fe (Unpaginated: p. 15 of pdf)

Cada qual cuenta la feria, / como en la feria le va.

Despreciar lo que se quiere (f. 135v)

dádivas quebrantan rocas. La monja Alférez (p. 144)

Mejor dirá el majadero, / de vn cabo me cerca duero, / y de otro peña tajada. $E l$ sufrimiento premiado (f. $253 \mathrm{v}$ )

Solo nos faltaua aquesto, / para echallo todo a doze. El valiente más dichoso don Pedro Gviral (f. 245v)

El amor todo lo vence. La doncella de labor (Obras 1.2, p. 365)

que es consejo de villano / después del conejo ido. $U n$ gusto trae mil disgustos (f. 8r)

Todo el dinero lo acaba. La toquera vizcayna (f. 134v)

que el oro todo lo vence. La toquera vizcayna (f. 140v)

Todo lo puede el amor. Olimpa, y Vireno (f. 185r)

El lobo está en la conseja. Como amante, y como bonrada (f. 14v)
Correas: A primera vayas, $y$ treinta y nueve hagas

Correas: Aun esto sería el diablo

Correas: Aunque seas prudente viejo, no desdeñes el consejo

Correas: Cada uno dice de la feria como le va en ella

Correas: Dádivas quebrantan peñas y hacen venir de las greñas

Núñez de Toledo: De vna parte me cerca Duero, y de otra peña tajada, no sé dónde me vaja

Correas: Echarlo a doce, y nunca se venda

Correas: El amor lo vence todo

Correas: El conejo ido; y el consejo, venido

Correas: El dinero todo lo puede y vence; todo lo puede el dinero; el dinero lo puede todo; el dinero lo acaba todo; todo le acaba el dinero

Correas: El lobo en la conseja 
El sastre de Piedras Albas, que ponía el bilo de su casa

El tiempo lo cura todo, o lo pone del lodo

[* Poner de lodo]

\section{En Cantalapiedra y \\ Cantalpino, canta la vieja con el buen vino \\ En baz y en paz de la Santa Madre Iglesia}

En la tardanza está el peligro

* En toda ocasión, más vale migaja de rey que ración de señor

Entre dos luces, es el tiempo de amanecer, $y$ el de anochecer

¿Es barro? Ya era barro ¿Era barro? No es barro
Mira en esso vna muger / nada pone de su casa. Amor, Privanza, y castigo (f. 163r)

y Florisel, y Niquea, / vienen ya puestos de lodo, / porque vienen prisioneros, / y las caras con reboços. Teágenes, y Clariquea (f. 134r)

que fue ponerse de lodo. Amor, Lealtad, y Amistad (f. 182v)

En Cantalapiedra dimos. Cumplir con su obligación (Obras 1.1, p. 281)

$\mathrm{Y}$ saliendo en az, y en paz Don Florisel de Niqvea (f. 45v)

que ay peligro en la tardança. Los amantes de Tervel (f. 247v)

A toda ley / migaja del Rey... Ser prudente y ser sufrido (p. 474)

secretario entre dos luces, / ni bien letrado ni agente.

La doncella de labor (Obras 1.2, p. 357)

Y fue barro / el quitar los hollejitos. El bijo del Serafín, San Pedro de Alcántara (Obras 1.2, p. 67)

Para que, pues era barro / verme por essos caminos... El Señor don Ivan de Avstria en Madrid (f. 231r)

¿es barro auer muerto a vn hombre? La Ganancia por la Mano (f. 198v)
Correas: El sastre de Piedras Albas, que ponía el bilo de su casa

Correas: El tiempo lo cura todo, o lo pone del lodo; Poner del lodo. (En menoscabo, y daño)

Correas: En Cantalapiedra y Cantalpino, canta la vieja con el buen vino

Correas: En haz y en paz de la Santa Madre Iglesia.

(Dícese de lo conforme en haz y en paz)

Correas: En la tardanza está el peligro

Correas: A toda ley, viva el Rey / A toda ley. morcilla de buey; mas a ley entera, yo de puerco la quisiera / En toda ocasión, más vale migaja de rey que ración de señor

Correas: Entre dos luces, es el tiempo de amanecer, $y$ el de anochecer. (Cuando ni bien es de día, ni de noche, y cuando uno está en duda, dice: Estoy entre dos luces; no sé cuál de las dos cosas haga)

Correas: ¿Es barro? Ya era barro ¿Era barro? No es barro. (Cuando se encarece algo por mucho, que no era tan fácil como el barro ni de tan poca estima, como el otro hace lo que le dan) 
Hablar de la mar, y en ella no entrar

Hijo de ruin padre, apellida de su madre

[??Si el bijo sale al padre, de duda saca a la madre]

Hombre de pelo en pecho, hombre de valor y hecho

* Hombre de pelo en pecho, hombre de valor y becho

Irse por su pie a la pila

foanes me fecit

La gata de Marirramos, que está muerta y caza ratos, o ratones

* La justicia de Peralvillo, que ahorcado el hombre bacíale pesquisa del delito
No, mas, ¿pues es barro esto? No ay vida como la bonra (f. 36r)

$\mathrm{Y}$ esta en que agora me traes, / ¿es barro?

Palmerín de Oliva (p. 38)

...y Ferrara / no es barro.

El valor perseguido (p. 12)

Eso es hablar de la mar.

Cumplir con su obligación

(Obras 1.1, p. 276)

en efeto dél nací, / y si el refrán Castellano / tiene fuerça de verdad, / solo aquesta calidad / me da ser más soberano. El segundo Séneca de España (f. 20r)

que es el lampiño hombre de pelo en pecho.

La monja Alférez (p. 88)

soldado de pelo en pecho. $L a$ mudanza en el amor (p. 166)

que muchas se van al don / por su pie como a la pila. $A$ lo becho no ay remedio, $y$ príncipe de los montes (Obras 1.1, p. 97)

En vna mano el broquel, / y en otra la de me fecit. La toquera vizcayna (f. 137r) desabrigas la de Iuanes. Despreciar lo que se quiere (f. 150r)

Y aquel que está en el esconce / de gata de Mari Ramos, / ¿qué diremos dél? El bijo del Serafín, San Pedro de Alcántara (Obras 1.2, p. 77) pueda hacerme gran señor, / o ponerme en Perlavillo! Ser prudente y ser sufrido (p. 472)
Correas: Hablar de la mar, y en ella no entrar; Hablar de la mar y estar en la tierra

Correas: Hijo de ruin padre, apellida de su madre. (A veces hay causas)

Correas: el hijo sale al padre, de duda saca a la madre.

(De sospecha)

Correas: Hombre de pelo en pecho, hombre de valor y hecho.

Correas: Irse por su pie a la pila. (Dícese por los que adultos y de edad se van a bautizar por su pie, y dáseles en rostro de ser moros o judíos)

Correas. Foanes me fecit. (Es escrito en espadas)

Correas: La gata de Marirramos, que está muerta y caza ratos, o ratones

Correas: La justicia de Peralvillo, que aborcado el hombre hacíale pesquisa del 


\section{CULL. PAREMIAS IN THE PLAYS OF JUAN PÉREZ DE MONTALBÁN}

La necesidad obliga a lo que el bombre no piensa

La ocasión hace al ladrón

La piedra y la palabra, no se recoge después de echada

Las paredes ban oídos, y los montes ojos, o las paredes tienen oidos y orejas

* Las paredes han oídos, y los montes ojos, o las paredes tienen oídos y orejas

* Las paredes han oídos, y los montes ojos, o las paredes tienen oídos y orejas

La verdad es hija de Dios y la mentira del diablo

Más tira moza, que soga

Más vale salto de mata que ruego de buenos, o de hombres buenos delito. (Peralvillo es cerca de Ciudad Real, donde justicia la Santa Hermandad)

Que los Trebacios obligan / a lo que el hombre no piensa. Don Florisel de Niquea (f. 45v)

Señor, en qualquier estado / la ocasión hace al ladrón. $A$ lo becho no ay remedio, $y$ príncipe de los montes

(Obras 1.1, p. 115)

que el amor está en el pecho, / como la piedra en la mano; / antes de arrojarla es llano, / que el dueño la sujetó; / pero en tirándola no, / que es piedra amor en su ser. / y atrás no puede boluer / si ya del alma salió. La deshonra bonrosa (ff. $69 \mathrm{v}-70 \mathrm{r}$ ).

Es que en tales ocasiones / suelen oír las paredes. Remedio, industria, y valor (Unpaginated: p. 12 of pdf)

oyen más las paredes.

La ventura en el engaño (p. 17 of pdf)

Esta noche os hablaré, / que es bien que me temorice, / porque escuchan las paredes, / y aun el Rey he visto allí. Amor, Lealtad, y Amistad (f. 181v)

Yo no, porque la verdad / es hija de Dios, y porque... Don Florisel de Niqvea (f. 49v)

Dexa repartir las vaças, / y tira luego la moça. Olimpa, y Vireno (f. 188r)

Válgame un salto de mata. El Valiente Nazareno (f. 95v)
Correas: La necesidad obliga a lo que el hombre no piensa

Correas: La ocasión hace al ladrón

Correas: La piedra y la palabra, no se recoge después de echada

Correas: Las paredes han oídos, y los montes ojos, o las paredes tienen oídos y orejas
Correas: La verdad es bija de Dios y la mentira del diablo

Correas: Más tira moza, que soga. (Tratan del amor, y fuerza de su poder)

Correas: En tanto y no, más vale salto de mata que a ruego de buenos / Más vale salto de mata que ruego de buenos, o de hombres buenos 
No cantan bien dos gallos en un gallinero

No puede ser más negro el cuervo que sus alas

Pian, piano se va a lontano

Piensa el ladrón que todos son de su condición

Que a la corta, que a la larga, todo se paga

Quiebra la soga por lo más delgado

\footnotetext{
* Quien canta, sus males espanta
}

Quien mucho babla, mucho yerra

Quien no parece, perece
Callad vos, que yo no quiero, / y he de cantar, vive Dios, / aunque os pese a vos Arnesto, / porque el que es honrado gallo / canta en qualquier gallinero. El valor perseguido (p. 23)

pues no puede ser más negro / el cuervo ya que las alas. Un gusto trae mil disgustos (f. 19r)

esso es irse pian, pian / en ayunas al infierno. El Señor don Ivan de Avstria en Madrid (f. 223v)

Piensa el ladrón, y esto baste. La doncella de labor (Obras 1.2, p. 395)

que a la larga o a la corta / se han de pagar...

Lo que son juicios del cielo (Obras 1.1, p. 327)

ved por cuál ha de quebrar. / Mas tú que estás rehusando / parecer mujer, y en nada / podrás parecerlo tanto, / como en decir tijeretas, / has de ser lo más delgado. La monja Alférez (p. 154)

Todos tañen, todos cantan. / discreto entretenimiento, / pues con aqueste contento / a sus tristezas espantan. El diuino Portugués San Antonio de Pádua (f. 157v)

Porque quien habla mucho, mucho hierra... Los

Templarios (Obras 1.2, p. 272)

¿Nunca has oído decir, / “quién no parece, perece?" Lo que son juicios del cielo

(Obras 1.1, p. 329)
Correas: No cantan bien dos gallos en un gallinero, $n i$ pueden bien cantar en un muladar, sin competir y pelear, como ni dos reyes en un reino reinar. Cada gallo canta en su gallinero, y el español en el suyo y en el ajeno, cuando es bueno

Correas: No puede ser más negro el cuervo que sus alas (See also refrains 16608 \& 16610, Zafra edition)

Correas: Pian, piano se va a lontano. (Dice el italiano); Núñez de Toledo: $A$ pian a pian se va a lontán. El italiano, Poco a poco van a lexos

Correas: Piensa el ladrón que todos son de su condición

Correas: Que a la corta, que a la larga, todo se paga. (Lo mal hecho)

Correas: Quiebra la soga por lo más delgado

Núñez de Toledo: Quien canta, sus males espanta

Correas: Quien mucho babla, mucho yerra

Núñez de Toledo: Quien no parece, perece 
* Quien tiempo tiene y tiempo aguarda, si no sufre silla, échenle albarda

Sal quiere este güevo

Ser de la boja

Si quieres vn día / bueno: bazte la barua: vn mes: bueno: mata puerco: vn año / bueno: cásate / vn siempre bueno: bazte clérigo

Tomar calzas de Villadiego y como dize el refrán, / quien no parece perece. Don Florisel de Niquea (f. 61r)

Échente vna albarda luego! Amor, Lealtad, y Amistad (f. 179r)

Sal quiere este huevo. Remedio, industria, y valor (Unpaginated: p. 5 of pdf)

También yo soy de la hoja. Olimpa, y Vireno (f. 184v)

Yo sé qué dize el refrán, / si quieres vn lindo rato, / bebe frío, si vna hora, / come en tu casa temprano: / si vn buen día, hazte la barba, / si vna semana, ve al baño, / si vn buen mes, mata vn lechón, / y si quieres vn buen año, / cásate con muger limpia. La más constante muger] (f. 211v)

No harás tal, porque sabré, / tomar las de Villadiego. La doncella de labor (Obras 1.2, p. 388)

Con lo qual, porque el cauallo / en la passada refriega / tomó las de villadiego.

Don Florisel de Niqvea (f. 46r)

Don Florisel, y Niquea / se afufaron, y yo coxo / las calças de Villadiego, / y a sus pisadas me acoxo. Teágenes, $y$ Clariquea (f. 133v)

Chocolate: Esto llaman en mi tierra / tomar las de Villadiego.

Pierres: $\mathrm{Y}$ en Francia escurrir el bola. Santo Domingo en Soriano (p. 29 of pdf).
Correas: Quien tiempo tiene y tiempo aguarda, si no sufre silla. échenle albarda

Correas: Sal quiere este güevo. (Dícenlo a la que es ya muy ufana de hermosa y galana)

Correas: Ser de la hoja, de los de Dios es Cristo; de los de Cristo me lleve. (Por valiente y de la carda)

Vallés: Si quieres vn día / bueno: hazte la barua: vn mes: bueno: mata puerco: vn año / bueno: cásate / vn siempre bueno: hazte clérigo
Correas: Tomar calzas de Villadiego / Tomar las de Villadiego; tomó las de Villadiego. (Para decir que alguno huyó de algún trance y aprieto...) 
Trae la soga arrastrando

Uno piensa el bayo, y otro el que le ensilla

* Váyase el diablo para puto

* Y a mi que me papen duelos

Yerros de amor, dinos son de perdonar

Yo estoy como perro con vejiga, que nunca falta un Gil que me persiga tomar las de Villadiego.

Palmerín de Oliva (p. 28)

da risa en lugar de miedo, /y

trae la soga arrastrando / para qualquiera desprecio. Segvnda parte del Séneca de España, Don Felipe Segvndo (f. 32v)

mas Gilote pensó el bayo / y es Germano quien le ensilla... Los Templarios (Obras 1.2, p. 216)

vaya el diablo para puto, / y toma el papel. Amor, Lealtad, y Amistad (f. 179v)

$\mathrm{Y}$ a mí que duelos me papen. La ventura en el engaño (p. 37 of pdf)

Perdonad doña Ana, el verme / en vuestra casa a estas horas, / que yerros de amor. Despreciar lo que se quiere (f. 153v)

va por el corredor / como perro con vejiga. La doncella de labor (Obras 1.2, p. 352)

Entrambos van, ¡vive Dios!, / como perro con vejiga. Lo que son juicios del cielo (Obras 1.1, p. 349)
Correas: Trae la soga arrastrando; traer la soga arrastrando. (Andar en peligro el que hace travesuras y hechos dignos de castigo)

Correas: Uno piensa el bayo, y otro el que le ensilla. (Bayo aquí se entiende caballo; uno, un negocio; otro, otro negocio diferente; que el caballo tiene un pensamiento y el que le ensilla tiene otro)

Váyase el diablo para puto. (Dando paz)

Correas: $Y$ a mí que me papen duelos. (Dícese cuando no meten en cuenta de comodidades a alguno)

Correas: Yerros de amor, dinos son de perdonar / Los yerros por amor, dinos son de perdonar

Correas: Yo estoy como perro con vejiga, que nunca falta un Gil que me persiga. (Por Antruejo atan vejigas hinchadas a la cola a los perros, con que van corriendo por las calles, y todos los gritan y los dan con lo que hallan). Como perro con vejiga, maza o calabaza. (Son con ella maltratados en los antruejos) 
Number of Paremias: Plays Categorized as of Undisputed Authorship

1. Don Florisel de Niquea (Segundo tomo de las comedias...): 7 [1633?-34?]

2. Lo que son juicios del cielo (Primero tomo de las comedias...): 3 [1632?-33?]

3. El bijo del Serafín, San Pedro de Alcántara (Primero tomo de las comedias...): 3 [1625?-29?]

4. La doncella de labor (Primero tomo de las comedias...): 4 [1632?]

5. Los amantes de Teruel (Primero tomo de las comedias...): 0 [1632?-33?]

6. La toquera vizcaina (Primero tomo de las comedias...): 4 [1628?-29?]

7. Olimpa, y Vireno (Primero tomo de las comedias...): 3 [1625?-29?]

8. Segunda parte del Séneca de España... (Segundo tomo de las comedias...): 1 [Ca. 1634-35]

9. Cumplir con su obligación (Primero tomo de las comedias...): 2 [Ca. 1620]

10. Despreciar lo que se quiere (Segundo tomo de las comedias...): 3 [Ca. 1624]

11. El señor don fuan de Austria en Madrid (Primero tomo de las comedias...): 2 [1627?-28?]

12. Los Templarios (Primero tomo de las comedias...): 2 [1625?-26?]

13. Como amante, y como honrada (Segundo tomo de las comedias...): 1 [Ca. 1634-35]

14. El valiente más dichoso don Pedro Guiral (Segundo tomo de las comedias...): 0 [1632?-33?]

15. A lo becho no ay remedio, y principe de los montes (Primero tomo de las comedias...): 2 [1633?]

16. La Ganancia por la Mano (Segundo tomo de las comedias...): 1 [Ca. 1620-24]

17. Teágenes, y Clariquea (Segundo tomo de las comedias...): 3 [1634-35]

18. De un castigo dos venganzas (Para todos): $:^{3} 0$ [1625-26]

19. El Valiente Nazareno (Segundo tomo de las comedias...): 1 [Ca. 1634-35]

20. La más constante mujer (Para todos): 1 [1625?-26?]

21. Amor, Privanza, y castigo (Primero tomo de las comedias...): 1 [1621?-22?]

22. El mariscal de Virón (Primero tomo de las comedias...): 0 [1630?-31?]

23. El segundo Séneca de España ${ }^{4}$ (Para todos): 1 [Ca. 1625-28?]

3. On the great success of this play, staged by the company of Manuel Vallejo, and some controversy surrounding it, see Dixon 1964, 46-48.

4. One of the two paremias from this play has to be inferred by the spectator/reader. Don Juan de Austria, the illegitimate son of Carlos V and Bárbara Blomberg, argues that he is of superior lineage to Prince Carlos I de Austria, who was the product of the marriage of Felipe II and the infanta María Manuela de Portugal: "en efeto dél nací, / y si el refrán Castellano / tiene fuerça de verdad, / solo aquesta calidad / me da ser más soberano" (f. 20r). In the table above I speculate that he might be alluding to the proverb: Hijo de ruin padre, apellida de su madre, or possibly to another: Si el hijo sale al padre, de duda saca a la madre. 
24. La deshonra honrosa (Segundo tomo de las comedias...): 1 [1620?-22?]

25. No bay vida como la honra (Para todos): 0 [1627?-28?]

Number of Paremias: Plays Categorized as Most Likely

BY PÉREZ de MONTALbáN

26. Remedio, industria, y valor: 2 [Ca. 1629-31?]

27. Como a padre y como a rey ${ }^{6}$ (Comedias escogidas II): 0 [1629?]

28. El valor perseguido: 7

29. Santo Domingo en Soriano: ${ }^{8}$ [Ca. 1629-31?]

30. La monja alférez:? 3 [1626?]

31. La puerta Macarena. Primera parte: ${ }^{10} 1$ [Ca. 1629-31?]

32. Palmerín de Oliva: ${ }^{11} 2$ [Ca. 1629-31?]

33. Un gusto trae mil disgustos: $:^{12} 3$ [1621?-25?]

34. La gitana de Menfis, Santa María Egipciaca: ${ }^{13} 0$ [1621?-25?]

5. Published only as a suelta, Bacon includes this play in his list of those that are genuine (430). Parker lists it in the section on "Plays Published as sueltas" with no commentary $(1975,64)$. The edition of the play that I have consulted at the Cervantes Virtual website is unpaginated, so I provide the number of the page when saved as a pdf document.

6. One copy of Comedias escogidas II that I have consulted, the second edition printed in 1837, is defective, reproducing only the beginning of the Pérez de Montalbán play, followed by text from El yerro del entendido, by Juan de Matos Fragoso (whose Comedias escogidas were also published by Ortega in 1828). The volume continues on to include the other plays in the Matos Fragoso work. The first edition of 1831 correctly includes Como a padre y como a rey as well as La más constante muger (also included in Para todos). Bacon includes Como a padre y como a rey in his list of genuine plays (428) and Dixon opines that "it must be regarded as certainly authentic" $(2013,523)$.

7. Although included among the "Suppositious Dramas" by both Bacon (450) and Parker (1975, 65), the latter adds that this suelta was considered to be "probably his" [Pérez de Montalbán's] by Dixon. Bacon indicates that it "reads much like our author's work" (450).

8. Published only as a suelta, Bacon includes this play in his list of those that are genuine (430). The edition of the play that I have consulted at the Cervantes Virtual website is unpaginated, so I provide the number of the page when saved as a pdf document.

9. Bacon considers this to be one of the genuine plays (430). Parker however, based on a review of Profeti's book by Victor Dixon, posits that it may be by Luis Belmonte Bermúdez $(1975,64)$. To the best of my knowledge, Dixon's is the only dissenting voice in attributing the play to Pérez de Montalbán.

10. Included among the genuine plays by Bacon (430) and "Those Published as sueltas" by Parker $(1975,64)$.

11. Published both as a suelta and in Parte XLIII. Comedias de diferentes autores (Zaragoza 1650), Parker includes it in his list of "Plays Attributed to Montalván in other Collections" $(1975,64)$ while Bacon includes it in the list of genuine works (430).

12. This play apparently escaped the attention of Bacon. Parker $(1975,63-64)$ indicates that it was published in both Parte XXIX. Doce comedias de Lope de Vega y otros autores (Huesca 1634) and in Parte XXIX Comedias de diferentes autores (Valencia 1636).

13. This play, published as a suelta only, is considered genuine by Bacon (429) and included in the list of "Those Published as sueltas" by Parker $(1975,63)$. 
35. La puerta Macarena. Segunda parte: $:^{14} 0$ [Ca. 1629-31?]

36. Los desprecios en quien ama: ${ }^{15} 0$ [1624?-1625?]

\section{Number of Paremias: Plays Categorized as of Uncertain, Dubious or Spurious ATtribution}

37. Amor, Lealtad, y Amistad ${ }^{16}$ (Segundo tomo de las comedias...): 6 [Ca. 1620-24]

38. El sufrimiento premiado ${ }^{17}$ (Segundo tomo de las comedias...): 2 [1622?-24?]

39. Ser prudente y ser sufrido ${ }^{18}$ (Comedias escogidas I): 2 [Early]

40. El dichoso en Zaragoza: ${ }^{19} 0$

41. El diuino Portugués San Antonio de Pádua ${ }^{20}$ (Segundo tomo de las comedias...): 2 [1621?-23?]

42. La mudanza en el amor: $:^{21} 2$

43. La ventura en el engaño:22 2

14. Included among the genuine plays by Bacon (430) and "Those Published as sueltas" by Parker $(1975,64)$.

15. Bacon accepts the play as genuine and notes that it was performed by the company of Andrés de la Vega on October 22nd, 1625 (337). Parker also concurs that the play is by Montalbán (1952, 204).

16. Based on the fact that two of Pérez de Montalbán's friends published this play after the dramatist's death with Sebastián Francisco de Medrano as its author, and that the action takes place in the span of 24 hours, something not found in any of Pérez de Montalbán's other plays, Dixon concludes that it is in fact the work of Sebastián Francisco de Medrano, although he does concede that its versification is similar to that found in other plays by Pérez de Montalbán (1961, 100-03). Bacon, however, includes it among the genuine plays (428). In his book on our dramatist, Parker follows the lead of Dixon and deems it "spurious" $(1975,53)$. However, in an earlier article he had included it among a group of "Authentic, Undated Plays" (1952, 194).

17. Dixon argues that this is a lost play by Lope de Vega due to versification patterns, character types and names, the language of allusion and the lack of a gracioso (1961, 105-08).

18. While Bacon includes this play in his list of those that are genuine (431). Dixon mentions in passing that in his view, it "cannot be dated and was probably not by Montalbán" (1964, 36, note 2).

19. Parker does not deal with this play at all. Bacon includes it in the list of "Suppositious Dramas" (441) and points out that in its publication history, both as a suelta and in published Partes, it has been variously attributed to Pérez de Montalbán, Moreto and Lope de Vega.

20. Dixon indicates that the play was attributed in an earlier and more authoritative manuscript to Bernardino de Obregón, and on this basis decides that it was not written by Pérez de Montalbán $(1961,103)$.

21. Included by Bacon among "The Suppositious Dramas of Montalván” (444), it is not considered at all by Parker.

22. Not considered at all by Bacon nor Parker, this play exists in manuscript (Biblioteca Nacional, BNE 16.654) and as a published suelta. The edition of the play that I have consulted at the Cervantes Virtual website is unpaginated, so I provide the number of the page when saved as a pdf document. 


\section{Lucha de amor y amistad: $:^{23} 1$}

45. El principe prodigioso y defensor de la fe: $:^{24} 1$

46. La lindona de Galicia:25 0

We see from this data that Pérez de Montalbán was remarkably consistent in his utilization of proverbs and refrains in his plays, ranging in number between zero and seven. Parker distinguishes between a first period in the production of Pérez de Montalbán, which is made up of plays written up to about 1629 , and a second period from 1630 on $(1952,193)$. The 22 plays definitely or probably by Pérez de Montalbán and reliably dated in the early period up to 1629 have a total of 37 proverbs and refrains, which is an average of 1.68 per play. Those reliably attributed to the later period and judged to be authentic include a total of 22 proverbs and refrains in 11 plays, an average of 2. This slight but significant increase is probably due to positive audience reception resulting in an increased demand. The 10 plays deemed uncertain, dubious or spurious feature 18 proverbs and refrains, with an average of 1.8 per play. If we were to include in our count the set phrases and other "common formulas of the Spanish language" that Correas included in his compilation (see appendix), the picture is vastly different.

In this latter case, the 25 plays included in the early period that are deemed indisputably genuine would have a total of 161 paremias, with an average frequency of 6.44 per play. The 11 plays that are thought to be probably by Pérez de Montalbán would include a total of 35 paremias, with an average frequency of 3.5 per play. Finally, the 10 plays that have been deemed "suppositious" would feature a total of 33 paremias, for an average of 3.3 per play. Thus, it is clear that the more authentic a play has been judged, the higher its average number of paremias. If we were to consider the dates of

23. Bacon points out that this play, which he includes among the "Suppositious Dramas of Montalván", "is identical with Lope's Amistad y Obligación, except that the first twenty-nine lines of the latter are omitted in the former, together with the character of Belardo, and the few lines assigned to that character" (443-44). Parker does not consider it at all. The edition of the play that I have consulted at the Cervantes Virtual website is unpaginated, so I provide the number of the page when saved as a pdf document.

24. Parker does not deal with this play at all. Bacon includes it in the list of "Suppositious Dramas" (449) with the caveat that it has also been ascribed to both Moreto and Matos. He concludes that it "does not read like Montalván's work" (449). The edition of the play that I have consulted at the Cervantes Virtual website is unpaginated, so I provide the number of the page when saved as a pdf document.

25. Both Bacon (443) and Parker $(1975,65)$ consider this to be a "suppositious" play possibly written by Lope de Vega. 
composition of only those plays adjudged to be definitely or probably by Pérez de Montalbán in light of the two periods of production suggested by Parker, and excluding the problematic El valor perseguido whose date of composition was not addressed by this critic, we would find these results: the early phase of Pérez de Montalbán plays (up to 1629) would feature 97 paremias in 19 plays (5.105 paremias per play); a transitional phase of plays estimated to have been written between 1629 and 1631 would have a total of 18 paremias in 5 plays ( 3.6 per play). The mature period (from 1630 on) would tally 86 paremias in only 11 plays (7.818 per play). With this broader definition of paremia in play, it would appear that Pérez de Montalbán became more convinced of the value of giving a voice to popular locutions in his plays as he matured in his craft.

Whether we restrict our definition of paremia to proverbs, aphorisms, maxims and refrains, or broaden it to be more inclusive, we must still account for the function of the paremias in the plays of Spanish Golden age playwrights in general, and in Juan Pérez de Montalbán in particular. Using the studies of Jean Canavaggio on paremias in Lope de Vega and other Spanish Golden Age dramatists as her point of departure, Alexandra Oddo Bonnet identified the following strategies for the incoproration of proverbs and refrains in Golden Age dramatic texts: "Para embellecer el discurso poético o para amenizarlo, ora como argumentos de autoridad o instrumento interactivo en el desarrollo de la intriga" (170). But I would posit that the functions of paremias are more wide reaching than a mere embellishment of the poetic discourse.

On the most basic level, certain paremias serve the purpose of characterization, especially when uttered by members of the lower social classes. These would be the set refrains, phrases, idioms and popular expressions that do not presuppose any form of erudition on the part of the enunciator or the receptor. Teresa Rodríguez has observed that: "Lo significativo es que este tipo de expresiones ya acuñadas anclan al personaje en un espacio propio, constituyendo un discurso-retrato fácilmente reconocido por los espectadores, como lo había sido ya desde el primer teatro castellano el sayagués literario del pastor" (129). The paremias of greatest interest, whether they proceed from the learned tradition or the anonymous popular tradition, are those that tend to have a more didactic function in the plays, offering by means of an analogy a hidden gem of wisdom or moral commentary that might be too risky or indiscreet to voice directly. To cite a pair of examples from Pérez de Montalbán, 
Tomín, in $A$ lo becho no ay remedio, y principe de los montes, indirectly accuses Gila of being a cristiana nueva with the proverbial locution: "que muchas se van al don / por su pie como a la pila" (f. 12v). Correas clarifies the true meaning: "Dícese por los que adultos y de edad se van a bautizar por su pie, y dáseles en rostro de ser moros o judíos". In La donçella de labor, the gracioso Monçón asks his master Don Diego if he believes everything that the scheming Isabel tells him. Miffed at his intrusion, she chides him by reciting the truncated version of the refrain piensa el ladrón que todos son de su condición: "Piensa el ladrón, y esto baste" (f. 104v). In this way she is able to insult him and put him in his place without losing her decorum by reciting the paremia in full.

We have already seen that the use of a paremia in a play's title may serve as an incentive to lure a greater number of playgoers to pay the entry fee at the ticket booth of the corral de comedias, resulting in an economic benefit to the dramatists. Of more importance perhaps, the paremia, as a nugget of traditional knowledge transmitted from generation to generation, ${ }^{26}$ forms part of a shared linguistic and cultural code that establishes a cohesive bond between a dramatist and his audience, a bond mediated by the performers who convey them to the public. This communal discourse then, as Muñoz Aznar has observed, gave rise to a sense of complicity between the dramatist and his audience, a complicity that is even more acute when a proverb is cited in truncated form, inviting the audience to participate in the dramatic text and thus share in its creation by completing the paremia mentally, and understanding its application to the situation at hand during the course of the performance (193). To cite just one further example of the use of a truncated paremia, when Machín utters the following verses, the missing subject (soga) must be provided by the the receptors of his proverbial allusion, based on their familiarity with the proverb Quiebra la soga por lo más delgado:

ved por cuál ha de quebrar.

Mas tú que estás rehusando

parecer mujer, y en nada

podrás parecerlo tanto, como en decir tijeretas, has de ser lo más delgado. (La monja Alférez 154)

26. Even here we must exercise caution and agree with Almela Pérez, who points out that: "Los refranes expresan «una» sabiduría (?), o sea, un conocimiento, una actitud, una opinión, etc., no «la» sabiduría del pueblo" (145). 
What is more, the incorporation of paremias gives a voice within the dramatic text to the great silent majority of illiterate playgoers in the public theaters by endowing their traditional forms of oral expression with dignity and authority. Although many paremias in Spanish Golden Age dramatic texts are intended to provoke laughter, at the same time they allow us as modern receptors to capture the rich fabric of oral culture: "«esas voces que nos llegan del pasado», de sus refranes y proverbios, de sus canciones y cuentos, de sus parodias y chistes, de sus fábulas, capaces, solo ellos, de acercarnos un poco más a las almas de quienes las crearon" (Cascajero 112). In brief, then, paremias in Golden Age performances provide further evidence of an intentional democratic strategy by Lope (and others) to: "appeal to the tastes of the heterogeneous and undifferentiated vulgo, his desire to please the popular audience accentuated by his contempt for the expectations of the neoclassicist elite of the Real Academia" (Cañadas 24).

Space limitations preclude a more detailed analysis of the function of paremias in the plays of Juan Pérez de Montalbán, although we can say that he is not particularly innovative in their use. Rather, they constitute another shared dramatic convention that we find in most Spanish Golden Age playwrights. Pérez de Montalbán systematically incorporated paremias into most of his plays. What remains for future research to explore is whether the number and specific content of paremias in a given play might serve as an additional metric to help determine authorship for the disputed plays of Juan Pérez de Montalbán, and for those of other Golden Age dramatists. 


\section{Appendix: Popular Locutions, Set Phrases. Dialogisms aNd OTHER COMMON Formulas}

A boca llena

A brazo partido

A coces

A diestro y a siniestro

A burta cordel

A lo menos, del mal lo menos

Al pie de la letra

Andad al rollo

Andar de Herodes a Pilatos que aun Dios quiere que le piden, / con ser Dios, a boca llena. La más constante muger (f. $109 \mathrm{v}$ )

luchando a brazo partido. La puerta Macarena.

Primera parte (p. 2)

$\mathrm{O}$ quien te matara a cozes. Don Florisel de Niquea (f. 50v)

goza a diestro, y a siniestro. Olimpa, y Vireno (f. 193r)

miráuame a hurta cordel / como quien culpado estaua. Segvnda parte del Séneca de España, Don Felipe Segundo (f. 25r)

dixera del mal lo menos. El valiente más dichoso don Pedro Gviral (f. 248v)

Sí porque del mal lo menos. De vn castigo dos vengansas (f. $87 \mathrm{v}$ )

Y será según lo aduierto / al pie de la letra. La Ganancia por la Mano (f. 198r)

que en vez de amarla y quererla, / por no olerla, $y$ por no verla / al rollo, señor, te irás. Lo que son juicios del cielo (Obras 1.1, p. 322)

La puerta Macarena, Primera parte (f. 198r)

Por esso solo se dixo / aquel refrán de Pilatos. Como a padre y como a rey (p. 25, Cervantes Virtual suelta)
Correas: A boca llena.

(Alabando persona o cosa, se dice: puédese llamar docto a boca llena...

Correas: A brazo partido. (Así se asen los que luchan en paz). (Correas)

Correas: A coces. (Amenaza que forzará y obligará a coces hacer lo que deben)

Correas: $A$ diestro y a siniestro. (Ir destruyendo a todas manos)

Correas: A burta cordel. (Como tirar la piedra y esconder la mano; imitado del retirar conmaña el cordel del trompo)

Correas: A lo menos, del mal lo menos

Correas: Al pie de la letra. (Cuando se dice algo como está escrito, o como pasó, y también es amenaza, que lo ha de pagar al pie de la letra, como en ella se contiene)

Correas: Andad al rollo; idos al rollo; váyase al rollo de Ecija I Váyase al rollo que le estire. (Negando algo)

Correas: Andar de Herodes a Pilatos. (Cuando se anda a negociar con diferentes personas en diversas partes; 


\section{CULL. PAREMIAS IN THE PLAYS OF JUAN PÉREZ DE MONTALBÁN}

A pagar de mi bolsa. A pagar de mi dinero

A pie juntillas

A puto el postrero

Aquí fue Troya

* Aquí fue Troya

A tú por tú, como en taberna

Barbas buenas le dé Dios en el ánima y si son juez, letrado, procurador y escribano, viene mejor acomodada la metáfora de la Pasión)

Ay qué bellacos son ambos, / a pagar de mi dinero! Santo Domingo en Soriano (p. 29 of pdf)

Oste puto, si el viejo me sintiera, / negar a pies juntillas, / rehilándome van las dos rodillas. Despreciar 10 que se quiere $($ f. $152 \mathrm{v})$

A puto el postre a morir. El Mariscal de Virón (f. 111v)

Correas: A pie juntillas.

(Negar fuerte)

Correas: A puto el postrero. (Ir a porfía, cuál llegará el primero)

¿Jesucristo, aquí fue Troya! El bijo del Serafín, San Pedro de Alcántara (Obras 1.2, p. 121)

Correas: Aqui fue Troya.

(Cuando se ofrece dificultad, y más se dice burlando)

Esto es hecho Luzela, aquí fue Troya. Don Florisel de Niquea (f. 62r)

Aquí Dalida fue Troya. El Valiente Nazareno (f. 99r)

aquí fue troya señor. El segundo Séneca de España (f. 24r)

Aquí, Leonida, fue Troya. Remedio, industria, y valor (Unpaginated: p. 25 of pdf).

Palmerín aquí fue Troya. Palmerín de Oliva (p. 27)

ay Laura, aquí fue Troya. Amor, Lealtad, y Amistad (f. 194v)

hablaua tú por tú con las cabrillas. Don Florisel de Niqvea (f. 48r)

Vaya con Dios buenas barbas. La toquera vizcayna (f. 151r)
Correas: A tú por tú, como en taberna. (Trabarse, haberse)

Correas: Barbas buenas le dé Dios en el ánima. (Con fisga y desdén) 
Bien baya la madre que te parió

Buena manderecha os dé Dios

Cabe de paleta

* Cada loco con su tema. (f. 179r)

Coger en el lazo, en la trampa, en la ratonera, en el garlito

* Coger en el lazo, en la trampa, en la ratonera, en el garlito

Coger entre puertas

Comer arena

Como las niñas de los ojos

Correr parejas
Bien aya quien te parió. El Señor don Ivan de Avstria en Madrid (f. 229r)

Fuesse: déte Dios amén / buena manderecha hallá.

Como amante, y como bonrada (f. 20r)

El cabe está de a paleta. / ¡Tírale cuerpo de Dios! Cumplir con su obligación (Obras 1.1, p. 202)

cada loco con su tema. El dichoso en Zaragoza (f. 179r)

cogido me han en la trampa. Don Florisel de Niquea (f. 54r)

Pues vamos antes que bueluan, / y nos cojan en la trampa. El valiente más dichoso don Pedro Gviral (f. 234v)

Bueno fuera / cogerme en la ratonera. Remedio, industria, $y$ valor (Unpaginated: p. 13 of pdf)

Cogido no[s] han en el lazo; / en tierra dio el edificio. Ser prudente y ser sufrido (p. 487)

(Esto es habernos cogido, / como dicen, entre puertas). Los Templarios (Obras 1.2, p. 244)

y van a comer arena.

Los amantes de Tervel (f. 247r)

sois las niñas de mis ojos. Segunda parte del Séneca de España, Don Felipe Segondo (f. $33 \mathrm{v}$ )

Tu cólera, y tu hermosura / pudieran correr parejas. El bijo del Serafin, San Pedro de Alcántara (Obras 1.2, p. 24)
Correas: Bien haya la madre que te parió. (Es alabanza de buen hijo y buen talle, y de hermosura y virtud en hija)

Correas: Buena manderecha os dé Dios

Correas: Cabe de paleta. (Dar ocasión a un buen dicho).

Poner el cabe de paleta.

(Como en el juego de la argolla, dar a un buen dicho, o hecho)

Núñez de Toledo: Cada loco con su tema

Correas: Coger en el lazo, en la trampa, en la ratonera, en el garlito. (Haciendo algo)

Correas: Coger entre puertas. (Como a los perros dentro de casa, y apalearlos)

Correas: Comer arena. (Si no se trabaja)

Correas: Como las niñas de los ojos. (Querer o cuidar lo querido)

Correas: Correr parejas. (Por ser iguales) 
Cual digan dueñas

Cuelga su vida de un bilo

Colgado de un bilo

* Colgado de un bilo

Cuesta los ojos de la cara

Dar barato

Dar cantonada

Dar con los huevos en la ceniza

Dar con todo al traste que vengo qual digan

dueñas. Como amante, y como

bonrada (f. 6r)

de vn hilo tengo el coraçón pendiente Don Florisel de Niquea (f. $52 \mathrm{v}$ )

$\mathrm{El}$ alma tengo en un hilo. Como a padre y como a rey (p. 14, Cervantes Virtual suelta)

Mi vida / anda de un hilo pendiente. El valor perseguido (p. 15)

...que ya tenía / pendiente el alma de un hilo. Ser prudente y ser sufrido (pp. 478-79)

pues anda según la dieta / todo padre de poeta, / porque todo padre ayuna. / ¡Por un ojo de la cara / no hay un pan! El bijo del Serafin, San Pedro de Alcántara

(Obras 1.2, pp. 112-13)

no ha de auer en Roma vn miedo / por vn ojo de la cara, / todo le traigo conmigo. Amor, Privanza, y castigo (f. 163v)

porque ganando favores, / es fuerza que a mis amores / dieras algo de barato.

Lo que son juicios del cielo

(Obras 1.1, p. 361)

mas yo le daré si puedo / cantonada, antes de que tome / possessión en mi assadura / $\mathrm{y}$ dominio en mis pulmones. Don Florisel de Niquea (f. 50r)

Por Dios, que hemos dado con / los huevos en la ceniza. La doncella de labor (Obras 1.2, p. 349)

(con todo al traste se dio). La doncella de labor

(Obras 1.2, p. 346)
Correas: Cual digan dueñas. (Por tratar y poner mal)

Correas: Cuelga su vida de un bilo. (El que está en peligro, o a pique de morir); Colgado de un bilo. (Estar en peligro; lo que colgado de los cabellos)

Correas: Cuesta los ojos de la cara. (Por lo caro)

Correas: Dar barato.

(Los que ganan al juego)

Correas: Dar cantonada.

(Irse callando; tómase de dar vuelta a trascantón, trasponerse y desaparecerse)

Correas: Dar con los huevos en la ceniza. (Por caer la cosa al mejor tiempo)

Correas: Dar con todo al traste. (por derribarlo). Dar al traste. (Es perderse la nave por dar en roca o navío) 
Dar del pan y del palo

Dar en caperuza

Dar en el blanco

Dar en rostro

* Dar jabón

Darle dos higas

Dar matraca

Decir en buen romance
( $\mathrm{iAl}$ traste / habemos dado con todo!) La doncella de labor (Obras 1.2, p. 396)

pregunté --por no dar con todo al traste--.

Lo que son juicios del cielo

(Obras 1.1, p. 402)

que he dado con todo al atraste [sic] Teágenes, $y$ Clariquea (f. 116v)

tú harás que dé con la embaxada al traste. Los desprecios en quien ama (p. 21)

no me dio del pan y el palo, / sino del palo no más. La gitana de Menfis, Santa María Egipciaca (p. 19) nos van dando en caperuza, / como dicen los muchachos. Lo que son juicios del cielo (Obras 1.1, p. 389)

muy lejos del blanco das. Cumplir con su obligación (Obras 1.1, p. 188)

porque el amor templará, / y aun en rostro le dará. El Señor don Ivan de Avstria en Madrid (f. 230r)

Déxame dalla vn jabón. $E l$ sufrimiento premiado (f. 259r) dar dos higas de tu parte. Como amante, y como bonrada (f. 1v)

Verá que me da matraca, / voto al Sol que diera vn osso. Segunda parte del Séneca de España, Don Felipe Segondo (f. 26v)

y me da matraca luego.

Santo Domingo en Soriano (p. 26 of pdf)

Y çampóse allá dentro en buen romance. Don Florisel de Niqvea (f. 62v)
Correas: Dar del pan y del palo, para hacer buen hijo del malo. / Dar del pan y del palo (Por sustento y castigo)

Correas: Dar en caperuza. (Es aporrear y sobrepujar)

Correas: Dar en el blanco. (Por acertar el negocio)

Correas: Dar en rostro. (Es enfadar, y dar hastío una cosa, zaherirle diciéndole sus faltas, darle en rostro, u ofenderle)

Correas: Dar jabón. (Por una reprensión)

Correas: Darle dos higas

Correas: Dar matraca.

(Lo mismo que dar baya)

Correas: Decir en buen romance. (Por decir claras las cosas) 
Descubrir la bilaza

Dicho y becho

Dios la alumbre con bien

Echaba chispas

Echa cantos: por loco, o tonto

Echar a perder

Echar el resto

Echar la casa por las ventanas he de descubrir la ilaça, / y dar con todo en el suelo. El valiente más dichoso don Pedro Gviral (f. 244r)

Ellas vienen, dicho y hecho. $A$ lo becho no ay remedio, $y$ principe de los montes (Obras 1.1, p. 129)

Dios nos alumbre con bien. Olimpa, y Vireno (f. 180v)

Esto es ir echando chispas / propiamente... El bijo del

Serafin, San Pedro de Alcántara (Obras 1.2, p. 82)

póngome de ministro, aunque hecho cantos. Segonda parte del Séneca de España, Don Felipe Segundo (f. 34r)

Que no lo echará a perder. Los amantes de Tervel (f. 247v)

Todo le he echado a perder.

Don Florisel de Niquea (f. 55v)

Si el amor es gran poeta / oy deues echar el resto, / porque la ocasión te ha puesto / vn soneto de a paleta. A lo becho no ay remedio, $y$ príncipe de los montes (Obras 1.1, p. 118)

Ya echó el resto mi fortuna. Cumplir con su obligación (Obras 1.1, p. 248)

Echó mi fortuna el resto. El Señor don Ivan de Avstria en Madrid (f. 227v)

Echó mi fortuna el resto. De vn castigo dos vengansas (f. $87 \mathrm{v}$ )

Echó el resto mi fortuna. El valor perseguido (p. 11)

Si yo en tu pellejo estuuiera / ya yo el bodegón huuiera /
Correas: Descubrir la bilaza. (Hacer lo que no prometió ni correspondía, y descubrirse él mismo con sus obras)

Correas: Dicho y becho. (Denotando presteza en hacer tras el decir)

Correas: Dios la alumbre con bien. (A la preñada)

Correas: Echaba chispas; echar chispas. (Es del hierro ardiente, y trasládase a los que se enojan y dicen mucho enojados)

Correas: Echa cantos: por loco, o tonto. (Es un loco echacantos)

Correas: Echar a perder. (Por maltratar y destruir)

Correas: Echar el resto. (Por aventurarlo todo, poner todo esfuerzo; echó el resto; cumplió largamente; hizo todo su poder)

Correas: Echar la casa por las ventanas. (Dícese de uno que 
Echar la llave

Echar las entrañas

Echarse con la carga

En el pico de la lengua lo tengo

Entre dos aguas

Entre dos luces, es el tiempo de amanecer, $y$ el de anochecer

En un tris

Erre Erre dice Erre de no echado por la ventana. Como amante, y como bonrada (f. 15r)

que es echar a todo el sello. La toquera vizcayna (f. 143r)

Porque los bofes / echarás, y las entrañas, / si dessa suerte me comes. Don Florisel de Niqvea (f. 50r)

con la carga te has echado. Cumplir con su obligación (Obras 1.1, p. 204)

En el pico de la lengua / lo tuve por vida mía. La doncella de labor (Obras 1.2, p. 418)

el alma entre dos aguas, y cien olas. Despreciar lo que se quiere (f. 149v)

secretario entre dos luces, / ni bien letrado ni agente.

La doncella de labor

(Obras 1.2, p. 357)

dio por blancos arcaduzes / lágrimas entre dos luzes / si saldrán, o no saldrán. De vn castigo dos vengansas (f. $88 \mathrm{v}$ )

En vn tris está mi vida. Los amantes de Tervel (f. 237r)

Conforme los hombres fueren, / que ay amantes espantajos / que se estarán riñó y tomó enojo, que quiso echar la casa por las ventanas; más se usa en gracia)

Correas: Echar la llave. (Lo que echar el fallo, el sello; dar conclusión)

Correas: Echar las entrañas. (Echar las tripas, con asco o accidente, y afanar mucho, como echar los bofes y la hiel)

Correas: Echarse con la carga. (Por acabarse de enojar con efecto; dar con todo en tierra, perdiendo la paciencia y sufrimiento: comparación de la bestia, que se echa la carga por no poder sufrirla ni llevarla)

Correas: En el pico de la lengua lo tengo. (Cuando se va a acordar algo y no acaba)

Correas: Entre dos aguas. (Por estar en duda)

Correas: Entre dos luces, es el tiempo de amanecer, $y$ el de anochecer. (Cuando ni bien es de día, ni de noche, y cuando uno está en duda, dice: Estoy entre dos luces; no sé cuál de las dos cosas haga)

Correas: En un tris. (Denota suma brevedad, como la de un golpe; tómase del sonido de una cosa que se quiebra, como de vidrio o barro, y significa también el punto de peligro en que estuvo algo para caerse, o quebrarse...)

Correas: Erre. (...) de aquí sale tomar el nombre erre solo a muchos propósitos 


\section{CULL. PAREMIAS IN THE PLAYS OF JUAN PÉREZ DE MONTALBÁN}

erre erre / mareando las esquinas, / y gastando las paredes, / todo el día en vna calle. La toquera vizcayna (f. 137r)

Ese es otro capitulo

Es hablar en desierto

Estar con el pie en el estribo

Ganar por la mano

* Ganar por la mano

Hablar a la mano
Capítulo de otra cosa, / que viene Matusalén. El valiente más dichoso don Pedro Gviral (f. 243r)

esto es hablar en desierto. El bijo del Serafin, San Pedro de Alcántara (Obras 1.2, p. 75)

Ya estoy el pie en el estribo. El bijo del Serafín, San Pedro de Alcántara (Obras 1.2, p. 44) estando el pie en el estriuo. Segunda parte del Séneca de España, Don Felipe Segvndo (f. 40r)

Por la mano, señor, me auéis ganado. Los amantes de Tervel (f. 242r)

y ganéte por la mano. $L a$ Ganancia por la Mano (f. 225r)

en todo quiso ganarme / por la mano. Amor, Lealtad, y Amistad (f. 179r)

que pude Lisardo alçar / para ganar por la mano. Amor, Lealtad, y Amistad (f. 182r)

mi voluntad solo siente / ver que ganado me hayáis / por la mano en declarallo. Ser prudente y ser sufrido (p. 453)

¡Oho cómo pica el bergante! $/$ ¡Por Dios, que estaba sin bragas / el hortelano, o el Fraile / que le plantó! Mas denotando firmeza, y porfía afirmando o negando; con ejemplos se hará más claro: Erre Erre dice Erre de no (...) Fulando siempre dice erre erre al oficio, que es sin faltar de él día

Correas: Ese es otro capitulo. (Casi lo que "Eso es de otra cuba", "Esa es otra")

Correas: Es hablar al aire; es hablar en desierto, y a las piedras, o a las paredes.

(Cuando no quieren oír, y no se habla con efecto); Dar voces en desierto; Es predicar en desierto]

Correas: Estar con el pie en el estribo. (Del que está muy de camino)

Correas: Ganar por la mano. (Ir primero que otro)

Correas: Hablar a la mano. (Estorbar hablando al punto que el otro va a tirar el cabe, o herrón, para que no acierte) 
Hablar de talanquera

Hacer la mamona

Hacer su agosto

Irse a la mano

Irse por los cerros de Úbeda

La paz de Francia

Las coplas del perro de Alba no importa, / que el antídoto suave / le pondrá como merece. / Nadie a la mano me hable. El bijo del Serafin, San Pedro de Alcántara (Obras 1.2, p. 118)

¡Cómo estás en talanquera / eres Gilote valiente! Los Templarios (Obras 1.2, p. 185)

¿Yo lo he de hazer la mamona? El Valiente Nazareno (f. 95r)

y hazen su Agosto con ellas. Los amantes de Tervel (f. 246v)

con los relieves hazemos / Pierres, y yo nuestro agosto. Santo Domingo en Soriano (p. 36 of pdf)

Vaya, váyase a la mano. El bijo del Serafin, San Pedro de Alcántara (Obras 1.2, p. 64)

y es echar por essos cerros / de Úbeda, y de Baeza. Como a padre y como a rey (p. 11, Cervantes Virtual suelta)

no sé qué paces de Francia / rumiaron entre los dos. Lo que son juicios del cielo (Obras 1.1, p. 368)

sin coplas del Perro de Alva / los Comentarios de César. Como a padre y como a rey (p. 13, Cervantes Virtual suelta)
Correas: Hablar de talanquera. (Seguro)

Correas: Hacer la mamona. (Dícese al que se hace befa, o molestia; y por sujetar, y poder más)

Correas: Hacer su agosto. (Por aprovecharse)

Correas: Irse a la mano; vóime a la mano; váyase a la mano. (Por no hacer exceso)

Correas: Irse por los cerros de Úbeda. (Cuando uno en lo que dice va muy remoto de lo ordinario, y cuando se excusa con razones extraordinarias, o el que se pierde en la lición de oposición, o sermón, o va lejos del tema)

Correas: La paz de Francia. (Por besarse, porque lo usan allá por cortesía en las visitas entre conocidos y parientes)

Correas: Las coplas del perro de Alba. (Por cosa de poco valor: no lo estimo en las coplas del perro de Alba; no se me da las coplas del perro de Alba. Son vulgares, y tratan una querella de los judíos contra el perro de Antón gentil porque los mordía y desgarraba la ropa, y no a los cristianos; como que lo sabía diferencia) 
Leer la cartilla; leíle la cartilla

* Leer la cartilla

Mal lance echó

* Meterse en petrera

Mirar de so capa

Ni oste ni moste, o ni uste ni muste

Ni por lumbre

No dije esta boca es mía

No es cosa

No le arriendo la ganancia
Luego a solas le agarré, / y leíle la cartilla. Segunda parte del Séneca de España, Don Felipe Segvndo (f. 25r)

Bien la lee la cartilla, / la tercera de Calisto. $E l$ sufrimiento premiado (f. 253r)

mal lance avemos echado. $L a$ más constante muger (f. 212r)

En linda petrera estoy. $E l$ sufrimiento premiado (f. $259 \mathrm{v}$ )

y yo también le miraua / a socapa de rigor. Segvnda parte del Séneca de España, Don Felipe Segvndo (f. 25r)

sin dezir oste, ni moste.

Don Florisel de Niqvea (f. 46r)

ni por lumbre, ni por pienso / ofendamos las mugeres. Olimpa, y Vireno (f. 195v)

porque si alguno me sale / no diré: Esta boca es mía, / no por vida de mi madre. Olimpa, y Vireno (f. 177v)

que ninguno, aunque me ve / después de que me enflamenqué / me dize, esta boca es mía. El Señor don Ivan de Avstria en Madrid (f. 231r)

no hay que hablar, no diré esta boca es mía. Como a padre y como a rey (p. 8, Cervantes Virtual suelta)

Pues dar la muerte al Marqués / no es cosa. Lo que son juicios del cielo (Obras 1.1, p. 317)

No me arriendo la ganancia. La deshonra honrosa (f. 88r)
Correas: Leer la cartilla; leíle la cartilla. (Decir lo que ha de hacer; reñir a uno)

Correas: Mal lance echó.

(Cuando uno quedó burlado en lo que pretendía)

Correas: Meterse en petrera. (Por meterse en obligación)

Correas: Mirar de so capa. (Disimulado; a traición)

Correas: Ni oste ni moste, o ni uste ni muste. (Cuando no se habló palabra)

Correas: Ni por lumbre. (Dícese negando y vedando hacer algo); Ni por pienso; lo que ni por lumbre. (Negando y vedando)

Correas: No dije esta boca es mía: no dijo no hablando palabra; Sin decir esta boca es mía. (Estar sin hablar ni quejarse)

Correas: No es cosa. (Dícese desagradándose de algo)

Correas: No le arriendo la ganancia. (Al que se cree que tendrá daño) 
Nonada entre dos platos

Oiste, puto

Pagar el escote

* pagar el escote

Pared y medio

Pegósela de puño

Poner los pies en polvorosa

Poner tierra en medio
Por esto solo se dixo / que era nada entre dos platos. Olimpa, y Vireno (f. 193r)

Oste puto, guarda Pablo. Segunda parte del Séneca de España, Don Felipe Segundo (f. 30r)

Oste puto, si el viejo me sintiera, / negar a pies juntillas, / rehilándome van las dos rodillas. Despreciar lo que se quiere (f. $152 \mathrm{v}$ )

Oste puto, vn cirujano / que me sangre he menester. Remedio, industria, y valor (Unpaginated: p. 13 of pdf)

Oste puto. La puerta Macarena. Segunda parte (p. 12)

desta vez pago el escote. Don Florisel de Niquea (f. 50r)

Pagará o [sic] escote. La lindona de Galicia (p. 27)

mas si estoy pared en medio / de su casa, mal podré.

Lo que son juicios del cielo

(Obras 1.1, p. 322)

¿no viues pared en medio / de mi casa? Los amantes de Tervel (f. 240r)

viuía pared en medio / de mi casa... Los amantes de Tervel (f. 251r)

de puño me la pegó. $L a$ Ganancia por la Mano (f. 218v)

poner pies en polurosa, / que lleuar en caperuça. El Mariscal de Virón (f. 128r)

(Aquí poner tierra en medio / importa). El bijo del Serafin, San Pedro de Alcántara

(Obras 1.2, p. 29)
Correas: Nonada entre dos platos. (Cuando lo que nos dan es nonada o muy poco)

Correas: Oíste, puto
Correas: Pagar el escote.

(Por la comida o daño)

Correas: Pared y medio. (Para decir que no hay más de pared en medio de las dos casas)
Correas: Pegósela de puño /

Diósela de puño (Pegósela con treta y maña)

Correas: Poner los pies en polvorosa. (Por huir, escapar)

Correas: Poner tierra en medio. (Apartarse, huir) 
Púsose blanco como un papel

* Que os dé Dios salud; bueno es que Dios os dé salud

¿Qué tenemos, bijo o bija?

* ¿Quién te mete en dibujos?

Sacar a plaza, o a la calle

Sacar fuerzas de flaqueza

Salir de madre

Salir de paso

Sin porqué ni para qué

Tener a raya y que pongas tierra en medio.

El valor perseguido (p. 11)

Ya yo estoy como vn papel.

Los amantes de Tervel (f. 254v)

Tal te dé Dios la salud. Amor,

Lealtad, y Amistad (f. 183v)

¿Hy nuevas de regocijo? /

¿Qué tenemos, hija o hijo?

Lo que son juicios del cielo

(Obras 1.1, p. 324)

Todos tañen, todos cantan. / discreto entretenimiento, / pues con aqueste contento / a sus tristezas espantan. El diuino Portugués San Antonio de Pádua (f. 157v)

¿quién me ha metido en dibujos? (Amor, lealtad y amistad, f. 184v)

Beuí la purga, atención, / que sale mi vida a plaça. Don Florisel de Niquea (f. 54v)

Fuerças de flaqueza saco. Los amantes de Tervel (f. 244r)

salga de madre el rigor, / ya es odio lo que era amor / y diamante lo que cera. Olimpa, y Vireno (f. 184v)

perdón, que la razón / me haze salir de mi passo. Los amantes de Tervel (f. 245r)

que aquí vino con su amo / sin porqué, ni para qué. Lo que son juicios del cielo (Obras 1.1, p. 394)

si yo, si es menester que también vaya, / para tenerle
Correas: Púsose blanco como un papel. (Del que se turbó o espantó)

Correas: Que os dé Dios salud; bueno es que Dios os dé salud

Correas: ¿Qué tenemos, bijo o bija? (Es como decir sí o no, bien o mal)

Núñez de Toledo: Quien canta, sus males espanta

Correas: ¿Quién te mete en dibujos? (Entiéndese por embarazos, dificultades y enredos)

Correas: Sacar a plaza, o a la calle. (Por decir a voces lo secreto)

Correas: Sacar fuerzas de flaqueza. (Esforzarse, hacer de las tripas corazón)

Correas: Salir de madre. (Cuando un escaso hace alguna liberalidad, y en tales casos a semejanza del río que con creciente sale por las riberas; que madre se llama su camino ordinario)

Correas: Salir de paso. (Por apresurarse)

Correas: Sin porqué ni para qué. (Lo que se hace sin causa ni provecho)

Correas: Tener a raya. (Por tener sujetos) 
Tirta buera, por tírate afuera

Todo saldrá en la colada

Tomar mosca

Trocar los frenos

Un pan como unas nueces

Va de cuento

* Vase por los cerros de Úbeda

Váyase al rollo que le estire a raya, / aun que vn fracaso

en la jornada espere...

Don Florisel de Niqvea (f. 48r)

tírate a fuera, al infierno! Los Templarios (Obras 1.2, p. 221)

tu hermano, tírate afuera.

Remedio, industria, y valor (Unpaginated: p. 13 of pdf)

Todo saldrá en la colada. Don Florisel de Niquea (f. 54v)

Con mosca está la señora. La toquera vizcayna (f. 141v)

Este freno se trocó.

La doncella de labor

(Obras 1.2, p. 349)

por Dios que ha errado las damas, / como los frenos.

Despreciar lo que se quiere (f. 153v)

vengan a darme un pan como unas nueces. Los Templarios (Obras 1.2, p. 268)

Podrá ser: mas va de cuento. La toquera vizcayna (f. 146v, misfoliated as $140 \mathrm{v}$ )

Pues va de cuento, atención. El Señor don Ivan de Avstria en Madrid (f. 217v)

va de cuento, y va de susto. No ay vida como la honra (f. 46v)

Vive Dios que hemos dado / por essos cerros de Vbeda, y Baeza. El dichoso en Zaragoza (f. 181v)

Que vaya al rollo.

Cumplir con su obligación

(Obras 1.1, p. 210)
Correas: Tirta huera, por tírate afuera. (En lenguaje rústico)

Correas: Todo saldrá en la colada

Correas: Tomar mosca. (Por enojarse)

Correas: Trocar los frenos. (Trocarse cosas)

Correas: Un pan como unas nueces, como unas candelas, como unos piñones, como los dientes de la bocas. (Alabanzas que dan las mujeres al pan trigo; dar un pan como unas nueces, con ironía, por dar castigo)

Correas: Va de cuento. (Preámbulo para contar algo)

Correas: Vase por los cerros de Úbeda. (Las razones que van fuera de propósito)

Correas: Váyase al rollo que le estire. (Negando algo) 


\begin{abstract}
Chocolate, vete al rollo.
Santo Domingo en Soriano

(p. 32 of pdf)
\end{abstract}

Venir a la mano

Venir ancho

Venir de molde / Viénele de casta y se pone de la parte / del Marqués, si viene a mano. Lo que son juicios del cielo (Obras 1.1, p. 323)

pues no os viene a vos muy ancho / que vn Príncipe de este cuerpo...

Don Florisel de Niqvea (f. 60r)

ser gallinas los Lacayos, / les viene de casta, y molde. Don Florisel de Niquea (f. 49v)
Correas: Venir a la mano. (Esperar ocasión de pagarse de otro)

Correas: Venir ancho. (Estarle a uno bien)

Correas: Venir de molde /

Viénele de casta. (El que se parece a ruines padres)

\section{WORKS CITED}

Almela Pérez, Ramón. “¿Son los refranes un reflejo de la sabiduría popular?”. Paremia 5 (1996): 143-45.

Anscombre, Jean-Claude. "Reflexiones críticas sobre la naturaleza y el funcionamiento de las paremias". Paremia 6 (1997): 43-54.

Bacon, George William. The Life and Dramatic Works of fuan Pérez de Montalván: 1602-1638. New York: s.n., 1912.

Cañadas, Ivan. Public Theater in Golden Age Spain and Tudor-Stuart London: Class, Gender and Festive Community. Aldershot and Burlington: Ashgate, 2005.

Cascajero, Juan. "Oralidad e historia antigua: una nueva motivación para el estudio del universo paremiológico". Paremia 4 (1995): 105-16.

Correas, Gonzalo. Vocabulario de refranes y frases proverbiales. 1627. Ed. Rafael Zafra. Pamplona: Universidad de Navarra/Kassel: Edition Reichenberger, 2000.

Dixon, Victor. “Juan Pérez de Montalbán’s Segundo tomo de las Comedias". Hispanic Review 29.2 (April 1961): 91-109.

Dixon, Victor. "Juan Pérez de Montalbán's Para todos". Hispanic Review 32.1 (January 1964): 36-59.

Dixon, Victor. "New (and Ancient) Lights on the Life of Juan Pérez de Montalbán”. Bulletin of Spanish Studies 90.4-5 (2013): 509-34.

Jaime Gómez, José de, and José María de Jaime Lorén. "Índice de las obras clásicas de la literatura española, en cuyos títulos figuran refranes y frases hechas (siglos XV-XVIII)". Paremia 8 (1999): 301-06. 
López Castro, Armando. “Gil Vicente y los refranes”. Paremia 5 (1996): 31-42. Mieder, Wolfgang. "Consideraciones generales acerca de la naturaleza del proverbio". Paremia 3 (1994): 18-26.

Muñoz Aznar, Marta. "Textos literarios y personajes paremiológicos". Paremia 5 (1996): 193-98.

Navarro Domínguez, Fernando. "Hacia una nueva caracterización del concepto de paremia en su empleo lingüístico-discursivo". Paremia 2 (1993): 21-26.

Núñez de Toledo, Hernán. Refranes, o proverbios en romance, qve nvevamente colligió y glossó el Comendador Hernán Núñez, Professor eminentíssimo de Rhetórica, y Griego, en Salamanca. Van pvestos por la orden del A b c. Salamanca: En Casa de Juan de Cánova, 1555.

Oddo Bonnet, Alexandra. "Influencia del refrán en las intrigas de las comedias del Siglo de Oro español”. Paremia 20 (2001): 169-78.

OED: Oxford English Dictionary. Oxford: UP, 2017. <http://www.oed.com> [julio de 2017].

Parker, Jack Horace. "The Chronology of the Plays of Juan Pérez de Montalván”. PMLA 67.2 (March 1952): 186-210.

Parker, Jack Horace. Fuan Pérez de Montalván. Twaine's World Authors Series 352. Boston: G. K. Hall \& Co., 1975.

Pérez de Montalbán, Juan. Para todos: Exemplos morales, bvmanos, y divinos. En que se tratan diversas ciencias, materias y facoltades. Repartidos en los siete días de la semana. $Y$ dirigidos a diferentes personas. Madrid: Imprenta del Reyno. A costa de Alonso Pérez su padre, Librero de su Magestad, 1632.

Pérez de Montalbán, Juan. Primero Tomo de las Comedias del Doctor Ivan Pérez de Montalbán, Clérigo Presbitero notario del Santo Oficio de la Inqvisición, y natural de Madrid. Alcalá de Henares: Imprenta de Antonio Vázquez, Impressor de la Vniversidad, 1638.

Pérez de Montalbán, Juan. Segvndo tomo de las comedias del Doctor Ivan Pérez de Montalván, Clérigo Presbitero, Notario del Santo Oficio de la Inquisición. Madrid: Imprenta del Reyno. A costa de Alonso Pérez de Montalván, Librero de su Magestad, y padre del Autor, 1638.

Pérez de Montalbán, Juan. Como a padre y como a rey. Valencia: Imprenta de Joseph y Thomàs de Orga, 1781.

Pérez de Montalbán, Juan. Los desprecios en quien ama. Valencia: Imprenta de Joseph y Thomás de Orga, 1782.

Pérez de Montalbán, Juan. Comedias escogidas del Doctor fuan Pérez de Montalván. Tomo Primero. Madrid: Imprenta de Ortega y Compañía, 1827. 
Pérez de Montalbán, Juan. Comedias escojidas del Doctor Fuan Pérez de Montalván. Tomo Segundo. Madrid: Imprenta de Ortega, 1831.

Pérez de Montalbán, Juan. La monja Alférez de fuan Pérez de Montalbán. Ed.

Luzmila Camacho Platero. Newark, DE: Juan de la Cuesta, 2007.

Pérez de Montalbán, Juan. Un gusto trae mil disgustos. Alicante: Biblioteca Vir-

tual Miguel de Cervantes/Madrid: Biblioteca Nacional, 2010. <www.cervantesvirtual.com/nd/ark:/59851/bmc4b3m2>.

Pérez de Montalbán, Juan. El dichoso en Zaragoza. Alicante: Biblioteca Virtual

Miguel de Cervantes/Madrid: Biblioteca Nacional, 2010. <www.cervantesvirtual.com/nd/ark:/59851/bmcr21h7>.

Pérez de Montalbán, Juan. La mudanza en el amor. Alicante: Biblioteca Virtual

Miguel de Cervantes, 2010. <www.cervantesvirtual.com/nd/ark:/59851/ bmcx06p9>.

Pérez de Montalbán, Juan. Palmerín de Oliva. Alicante: Biblioteca Virtual Miguel de Cervantes/Madrid: Biblioteca Nacional, 2011. <www.cervantesvirtual.com/nd/ark:/59851/bmcbv819>.

Pérez de Montalbán, Juan. La gitana de Ménfis, Santa María Egipcíaca. Madrid: Ayuntamiento/Alicante: Biblioteca Virtual Miguel de Cervantes, 2011. <www.cervantesvirtual.com/nd/ark:/59851/bmcvh5v2>.

Pérez de Montalbán, Juan. La puerta Macarena. Segunda parte. Madrid: Ayuntamiento/Alicante: Biblioteca Virtual Miguel de Cervantes, 2011. <www. cervantesvirtual.com/nd/ark:/59851/bmc73708>.

Pérez de Montalbán, Juan. Remedio, industria, y valor. Santander: Ayuntamiento/Alicante: Biblioteca Virtual Miguel de Cervantes, 2012. <www.cervantesvirtual.com/nd/ark:/59851/bmcfn1s8>.

Pérez de Montalbán, Juan. Lucha de amor y amistad. Santander: Ayuntamiento/Alicante: Biblioteca Virtual Miguel de Cervantes, 2012. <www.cervantesvirtual.com/nd/ark:/59851/bmcjd5h1>.

Pérez de Montalbán, Juan. El Príncipe prodigioso y defensor de la fe. Santander: Ayuntamiento/Alicante: Biblioteca Virtual Miguel de Cervantes, 2012. <www.cervantesvirtual.com/nd/ark:/59851/bmcjw910>.

Pérez de Montalbán, Juan. La ventura en el engaño. Santander: Ayuntamiento/Alicante: Biblioteca Virtual Miguel de Cervantes, 2013. <www.cervantesvirtual.com/nd/ark:/59851/bmc5f0j5>.

Pérez de Montalbán, Juan. Obras de fuan Pérez de Montalbán 1.1. Kassel: Edition Reichenberger, 2013. 
Pérez de Montalbán, Juan. Obras de fuan Pérez de Montalbán. Vol. 1.2. Kassel: Edition Reichenberger, 2014.

Pérez de Montalbán, Juan. Santo Domingo en Soriano. Madrid: Ayuntamiento/Alicante: Biblioteca Virtual Miguel de Cervantes, 2016. <www.cervantesvirtual.com/nd/ark:/59851/bmc3n447>.

Pérez de Montalbán, Juan. El valor perseguido, y trayción vengada. Salamanca: Imprenta de la Santa Cruz, s.f.

Pérez de Montalbán, Juan. La puerta Macarena. Primera parte. Sevilla: Imprenta de Joseph Padrino, s.f.

Pérez de Montalbán, Juan. La ventura en el engaño. Suelta from the collection of the Biblioteca Menéndez Pelayo, Sig. 32762, s.l., s.f.

Postigo Aldeamil, María Josefa. "Contribución al estudio de los refranes en Gil Vicente”. Paremia 6 (1997): 499-504.

Real Academia Española Diccionario de Autoridades. <http://ntlle.rae.es/ntlle/ SrvltGUILoginNtlle>. [julio de 2017].

Rodríguez, Teresa. "Usos y funciones de las paremias en un discurso teatral: el Códice de Autos Viejos (segunda mitad del XVI)”. Paremia 20 (2011): 127-38.

Sevilla Muñoz, Julia. "Las paremias españolas: clasificación, definición y correspondencia francesa". Paremia 2 (1993): 15-20.

Sevilla Muñoz, Julia and Carlos Alberto Crida Álvarez. "Las paremias y su clasificación”. Paremia 22 (2013): 105-14.

Vallés, Pedro. Libro De Refranes: Copilado por el orde[n] del Abc: Enel qual se co[n]tienen quatro mil y trezie[n]tos refranes. El más copioso que hasta oy ha salido Impresso. Çaragoça: en casa de Juana Milian, viuda de Diego Hernandez, 1549.

Zuluaga, Alberto. "Sobre las funciones de los fraseologismos en textos literarios". Paremia 6 (1997): 631-40. 